\title{
Associations of Self-efficacy, Family Support, Peer Support, and Posyandu Facility, with Mother's Visit to Posyandu in Karanganyar, Central Java
}

\author{
Ernawati ${ }^{1,2,3)}$, Endang Sutisna Sulaeman4), Dono Indarto4) \\ 1)Vocational High School of Empat Lima Surakarta, \\ Nursing Academy Insan Husada Surakarta \\ 2)Amanah Insan Husada Sejahtera Foundation, Surakarta \\ 3) Masters Program in Public Health, Universitas Sebelas Maret \\ 4) Faculty of Medicine, Universitas Sebelas Maret, Surakarta
}

\begin{abstract}
Background: Integrated service delivery has been defined as "the organization and management of health services so that people get the care they need, when they need it, in ways that are userfriendly, achieve the desired results and provide value for money". In Indonesia, the integrated service delivery at the village level is called as posyandu (integrated health post) with the support of community health workers working together with formal primary health care workers. This study aimed to examine the associations of self-efficacy, family support, peer support, and posyandu facility, with mother's visit to posyandu in Karanganyar, Central Java.

Subjects and Method: This was an analytic observational study with a cross-sectional design. The study was conducted at 25 posyandus in Karanganyar, Central Java, from April 16 to May 15, 2018. A sample of 200 mothers was selected by simple random sampling. The dependent variable was mother's visit to posyandu. The independent variables were self-efficacy, family support, peer support, and posyandu facility. The data were collected by questionnaire and analyzed by a multilevel logistic regression using Stata 13 program.

Results: Mother's visit to posyandu was positively associated with self-efficacy $(b=1.90 ; 95 \mathrm{CI}=$ 0.43 to $3.36 ; \mathrm{p}=0.011)$, family support $(\mathrm{b}=2.24 ; 95 \% \mathrm{CI}=0.81$ to $3.67 ; \mathrm{p}=0.002)$, peer support $(b=1.98 ; 95 \% \mathrm{CI}=0.63$ to $3.34 ; \mathrm{p}=0.004)$, and posyandu facility $(\mathrm{b}=3.86 ; 95 \% \mathrm{CI}=1.93$ to 5.80 ; $\mathrm{p}<0.001)$. Posyandu had a contextual effect on mother's visit to posyandu with ICC $24.79 \%$.

Conclusion: Mother's visit to posyandu is positively associated with self-efficacy, family support, peer support, and posyandu facility. Posyandu has a considerable contextual effect on mother's visit to posyandu.
\end{abstract}

Keywords: integrated health post, mother's visit, self-efficacy, family support, multilevel analysis

\section{Correspondence:}

Ernawati. Vocational High School of Empat Lima Surakarta, Nursing Academy Insan Husada Surakarta. Email: 3rn4wati.ew@gmail.com

\section{BACKGROUND}

Toddler period becomes an important period in creating qualified human resources, especially in the golden (golden period) which is the period of 5 (five) years of life (Yigibalom, 2013). In this period, children undergo a golden period in the process of growth and development including various aspects that are very fundamental to the next life (Humaira and Journalists, 2016).
Failure to grow that occurs due to malnutrition in that period can have a bad impact on the next life. The stunted children have an average IQ of 11 points lower than that of non-stunted children. Lack of nutrition at an early age can also increase the risk of various degenerative diseases (heart and cancer) in adulthood (Reihana and Duarsa, 2012). 
The prevalence of under-fives in Indonesia based on the Basic Health Survey of 2013 shows that the thin ones were $19.6 \%$, very thin $12.1 \%$, and $37.2 \%$ stunted. This result tends to be bigger than the WHO target if compared to 2007 which was thinner $10 \%, 5 \%$ very thin, and $20 \%$ dwarf (Nazri et al., 2015). One of the efforts to reduce the morbidity and mortality rate of under-five children is through the health care of under-five children through community health centers (puskesmas) and integrated health service post (posyandu) (Nazri et al., 2015). Toddlers taken to posyandu will be monitored their nutritional status and get better health (Idaningsih, 2016).

Posyandu as the spearhead of health care system in society has a very big and strategic role in improving public health status. The key to organizational success such as posyandu is determined by management, resource support, and commitment and support of stakeholders, ie puskesmas as the constructor (Reihana and Duarsa, 2012). Posyandu management resources consist of management resources consisting of manpower, funds, materials, facilities and infrastructure (mateials), machinery, equipment/ technology to transform input into output, method, market, time, and information (Sulaeman, 2016).

The general concept used to know the visit to posyandu is the concept of Darmawan, (2010) that behavior is influenced by three main factors namely predisposing factor, which is manifested in knowledge and attitude. The enabling factors are manifested in the physical environment, the availability or unavailability of facilities or facilities, such as puskesmas, medicines, and reinforcing factors embodied in the attitude and behavior of officers and family support.
Posyandu located in Karanganyar District are about 1,405 posyandu. The existence of posyandu assisted puskesmas located in Karanganyar regency of 21 puskesmas. Based on the annual report of Karanganyar District Health Office data of May 2017, it shows that the average coverage of underfive weighing in Karanganyar Regency in 2017 amounted to $79.58 \%$, this means that it has not fulfilled the coverage target of underfive weighing that has been set in Minimum Service Standard (SPM) that is equal to $85 \%$. Based on the result of visitation coverage to posyandu, it was found that from 21 Puskesmas, there were only 6 puskesmas which coverage is above $85 \%$ that is that of working area of Jaten 1, Jaten II, Gondangrejo, Mojogedang I, Mojogedang II, and Kerjo community health centers.

\section{SUBJECTS AND METHOD \\ 1. Study Design \\ This was an analytic observational study with a cross sectional design. The study was conducted in Karanganyar, Central Java, from April 16 to May 15, 2018.}

\section{Population and Samples}

The target population of this study was mothers who had children under five in Karanganyar and visited posyandu. A sample of 200 mothers was selected for this study by simple random sampling.

\section{Study Variables}

The dependent variable was mother's visit to posyandu. The independent variables were self efficacy, family support, peer support, and facility.

\section{Study Instruments}

The validity test in this study was conducted on 20 mothers who have children under five in Karanganyar District and came to posyandu. The validity used was the content validity of the question items with the item-total correlation coefficient of 
less than 0.2 discarded and if necessary rewritten, whereas the face validity has been consulted with Dr. Endang Sulaeman dr., M.Kes as supervisor I of the researcher.

The reliability test in this study was conducted on 20 mothers who have children under five in Karanganyar District and came to posyandu. The reliability test was done by measuring variables using the SPSS 22 statistical program that can calculate the total-item correlation and Cronbach alpha.

\section{Operational Definition of Variables}

Self-efficacy was defined as maternal selfconfidence to access posyandu. The data were collected by questionnaire. The measurement scale was continuous, but for the purpose of data analysis, it was transformed into dichotomous.

Family support was defined as family involvement in providing emotional, assessment, instrumental, and informational support in order to increase the motivation of mothers to come to posyandu so that the health of children under five can be monitored properly. The data were collected by questionnaire. The measurement scale was continuous, but for the purpose of data analysis, it was transformed into dichotomous.

Peer support was defined as a friend of the same age with mothers who live in a mother's environment so that they follow or imitate the behavior performed by another mother to come to posyandu. The data were collected by questionnaire. The measurement scale was continuous, but for the purpose of data analysis, it was transformed into dichotomous.

Posyandu facility was defined as anything that can support the success of posyandu activities to be well organized. The data were collected by questionnaire. The measurement scale was continuous, but for the purpose of data analysis, it was transformed into dichotomous.

Mother's visit to posyandu was defined as maternal behavior to come and check their children to posyandu. The data were collected by questionnaire. The measurement scale was continuous, but for the purpose of data analysis, it was transformed into dichotomous.

\section{Data Analysis}

Data samples characteristics of self-efficacy, family support, peers, and posyandu resources are described in frequency and percent. Bivariate analysis was conducted using chi-square test with confidence interval (CI) and significance level $\mathrm{p}<0.05$. The relationship of variables studied was then analyzed by multilevel analysis model. Variables at level one that directly affect the individual include self efficacy, family support, peers, and posyandu resources, while the variable located at level two is posyandu. The magnitude of influence on level one is indicated by the regression coefficient (b). The magnitude of influence at level two is represented by a parameter called intra class corelation (ICC) or also called the varian partition component (VPC) using the STATA 13 program.

\section{Research Ethics}

The research ethics permit was obtained from the research ethics committee at DR. Moewardi hospital, Surakarta, Central Java, Indonesia. The research ethics included informed consent, anonymity, and confidentiality.

$\frac{\text { RESULTS }}{\text { 1. Univariate Analysis }}$

Table 1 showed that mothers with high selfefficacy were 112 people (56\%). Mothers with strong family support by 135 (67.5\%). Mothers with high peer by 137 (68.5\%). Mothers with good posyandu facility by 132 (66\%). 
Journal of Maternal and Child Health 2018, 3(3): 233-241

https://doi.org/10.26911/thejmch.2018.03.03.08

Table 1. Study subjects characteristics

\begin{tabular}{clcc}
\hline Independent Variables & n & \% \\
\hline $\mathbf{1}$ & Self-efficacy & & \\
& Low $(<29)$ & 88 & 44 \\
& High $(\geq 29)$ & 112 & 56 \\
2 & Family support & & \\
& Weak (<48) & 65 & 32.5 \\
& Strong ( $\geq 48)$ & 135 & 67.5 \\
3 & Peer support & & \\
& Low (<27) & 63 & 31.5 \\
& High ( $\geq 27)$ & 137 & 68.5 \\
4 & Posyandu facility & & \\
& Fair $(<27)$ & 68 & 34 \\
& Good $(\geq 27)$ & 132 & 66 \\
\hline
\end{tabular}

2. Bivariate Analysis Results

Table 2. Chi-square test results self-efficacy, family support, peers, and posyandu facility with mother's visit to posyandu

\begin{tabular}{|c|c|c|c|c|c|c|c|}
\hline \multirow{2}{*}{ Variable } & \multirow{2}{*}{ Category } & \multicolumn{2}{|c|}{$\begin{array}{c}\text { Mother's visit to } \\
\text { posyandu }\end{array}$} & \multirow{2}{*}{ OR } & \multicolumn{2}{|c|}{$95 \%$ CI } & \multirow{2}{*}{$\mathbf{p}$} \\
\hline & & No & Yes & & $\begin{array}{l}\text { Lower } \\
\text { Limit }\end{array}$ & $\begin{array}{l}\text { Upper } \\
\text { Limit }\end{array}$ & \\
\hline Self-Efficacy & $\begin{array}{l}\text { Low }(<29) \\
\operatorname{High}(\geq 29)\end{array}$ & $\begin{array}{l}29(33 \%) \\
8(7.1 \%)\end{array}$ & $\begin{array}{c}59(67 \%) \\
104(92.9 \%)\end{array}$ & 6.39 & 2.74 & 14.88 & $<0.001$ \\
\hline $\begin{array}{l}\text { Family } \\
\text { Support }\end{array}$ & $\begin{array}{l}\text { Weak }(<48) \\
\text { Strong }(\geq 48)\end{array}$ & $\begin{array}{l}26(40 \%) \\
11(8.1 \%)\end{array}$ & $\begin{array}{c}39(60 \%) \\
124(91.9 \%)\end{array}$ & $7 \cdot 51$ & 3.40 & 16.58 & $<0.001$ \\
\hline Peers & $\begin{array}{l}\text { Low }(<27) \\
\text { High }(\geq 27)\end{array}$ & $\begin{array}{c}28(44.4 \%) \\
9(6.6 \%)\end{array}$ & $\begin{array}{c}35(55.6 \%) \\
128(93.4 \%)\end{array}$ & 11.37 & 4.91 & 26.32 & $<0.001$ \\
\hline $\begin{array}{l}\text { Posyandu } \\
\text { facility }\end{array}$ & $\begin{array}{l}\text { Fair }(<27) \\
\text { Good }(\geq 27)\end{array}$ & $\begin{array}{c}34(50.0 \%) \\
3(2.3 \%)\end{array}$ & $\begin{array}{c}34(50.0 \%) \\
129(97.7 \%)\end{array}$ & 43.00 & 12.45 & 148.50 & $<0.001$ \\
\hline
\end{tabular}

\section{Multilevel Analysis Results}

Table 3 showed the results of a multivariate analysis that described the relationship of more than one independent variables which were self-efficacy, family support, peer support, and posyandu facility with mothers' visit to posyandu.

There was a relationship between selfefficacy and mothers' visit to Posyandu which was statistically significant. Mothers with high self-efficacy were more likely to visit the posyandu compared to mother who have low self-efficacy $(b=1.90 ; 95 \%$ $\mathrm{CI}=0.43$ to 3.36 ; $\mathrm{p}=0.011$ ).

There was a relationship between family support and mothers' visit to posyandu which was statistically significant. Mother who got strong family support were more likely to visit the posyandu compared to mothers who have lack of family support $(b=2.24 ; 95 \% \mathrm{CI}=0.81$ to $3.37 ; \mathrm{p}=0.002)$.

There was a relationship between peer and mothers' visit to posyandu which was statistically significant. Mothers who got high peer's influence were more likely to visit the posyandu compared to mothers who got low peer's influence $(b=1.98 ; 95 \%$ $\mathrm{CI}=0.63$ to $3.34 ; \mathrm{p}=0.004$ ).

There was a relationship between Posyandu facility and mothers' visit to Posyandu which was statistically significant. Mothers who have good posyandu facility were more likely to visit the posyandu compared to mothers who have poor Posyandu facility $(b=3.86 ; 95 \% \mathrm{CI}=1.93$ to 5.80; $\mathrm{p}<0.001)$. 
There was a contextual effect of Posyandu on mothers' visit to Posyandu $(\mathrm{b}=1.08 ; 95 \% \mathrm{CI}=0.10$ to $10.75 ; \mathrm{p}<0.001)$. ICC $=24.79 \%$ showed that the Posyandu condition in each strata has a contextual effect on the variation of the mothers' visit to the Posyandu by $24.79 \%$. The number was greater from the size of the role of thumb standard which was $8-10 \%$, then the contextual effect of Posyandu was shown from multilevel analysis which was very important to be noted. The table also showed a likelihood ratio of $\mathrm{p}<0.001$. This mean that there was a statistically significant difference between models regardless of contextual effect and models that looking at contextual effect. Posyandu with independent strata increased the possibility of mothers to visit the Posyandu rather than Posyandu with purnama and madya strata.

Table 3. Results multilevel logistic regression analysis on the effects of selfefficacy, family support, peer relations, posyandu facility, and mother's choice to visit posyandu

\begin{tabular}{lcccc}
\hline \multirow{2}{*}{ Independent Variable } & b & \multicolumn{2}{c}{ 95\% CI } & \\
& & $\begin{array}{c}\text { Lower } \\
\text { Limit }\end{array}$ & $\begin{array}{c}\text { Upper } \\
\text { Limit }\end{array}$ & p \\
\hline Fixed Effect & & & & \\
High self-efficacy & 1.90 & 0.43 & 3.36 & 0.011 \\
Good family support & 2.24 & 0.81 & 3.67 & 0.002 \\
High influenced peers & 1.98 & 0.63 & 3.34 & 0.004 \\
Good posyandu resources & 3.86 & 1.93 & 5.80 & $<0.001$ \\
Random Effect & & & & \\
Posyandu & & & & \\
Var. (constanta) & 1.08 & 0.10 & & \\
Intra Class Corelation & $24.79 \%$ & & & \\
N observation= 200 & & & & \\
Likelihood Ratio Test p $<0.001$ & & & & \\
\hline
\end{tabular}

\section{DISCUSSIONS}

\section{The relationship between self-effi- cacy and mother's visit to posyandu}

There was a relationship between selfefficacy and mothers' visit to posyandu. Mother who have high self-efficacy were more likely to visit the posyandu compared to mothers who have low self-efficacy. The result of this study was in line with a study by Kurniawan (2017), which stated that there was a relationship between selfefficacy and visit to posyandu. High selfefficacy level of respondents mean that the respondents were more confident that the behavior of the visit was right.

Self-efficacy was a belief about the ability to perform an expected action, selfefficacy was also the basis of a person to perform an action or control certain conditions (Bandura, 1994).

Self-efficacy affected the mechanism of human behavior, if someone was convinced of having the ability to produce something that was expected, then the individual would try to achieve it, but if the individual did not have the confidence to produce something expected, then he/she would not try to make it happen (Bandura and Locke, 2003).

In this study, most of the research subjects have high self-efficacy. This showed that some people have confidence to be able to visit the posyandu. High selfefficacy would encourage the beliefs of mothers who have children to further enhance their visit to the posyandu in order 
to monitor the growth and development of their chidlren every month.

\section{The relationship between family support and mother's visit to posyandu}

There was a relationship between family support and mothers' visit to Posyandu which was statistically significant. Mothers who got strong family support were more likely to visit the Posyandu compared to mothers who have lack of family support. The result of this study was also in line with a study by Rahman, Luthviatin and Istiaji, (2013), which stated that there was a meaningful relationship between family support and mothers' visit to Posyandu.

Families were two or more individuals who live in one house due to blood relations, marriage, or adoption. They interact with each other, have their own roles, create, and maintain a value (Sefrina and Latipun, 2016). The family was the core of a smallest social group of societies formed by marriage and a family consisted of a husband (father), wife (mother), and children (Yigibalom, 2013).

Family was a major support in maintaining health and played an important role in care and prevention of health in other family members. Therefore, the family must have knowledge about it (Burgess et al., 2005). If the knowledge of the family was better, the behavior would also be better, but if good knowledge was not accompanied by attitude, then the knowledge would be meaningless (Efendi et al., 2017).

In this study, most of the study subjects have good family support. This showed that some people have learned that providing good support to mothers who have toddlers would increase their motivation to visit the posyandu. Mothers who have good family support were more likely to visit a posyandu with greater intensity than mothers who did not get family support.

\section{The relationship between peer support and mother's visit to posyandu}

There was a relationship between peer and mothers' visit to posyandu which was statistically significant. Mothers who got high peer's influence were more likely to visit the posyandu compared to mothers who got low peer's influence. The result of this study was in line with a study by Rahman et al. (2013), which stated that there was a meaningful relationship between peer and mothers' visit to posyandu. Mothers who got peer support increased their intention to visit Posyandu rather than mothers who did not get support from peers.

Peers were a group of people of the same age and have the same social group as a schoolmate or coworker (Utami and Damayanti, 2012). Peer's influence could occur on several levels. Peer was one of the most significant sources of information in forming the knowledge, attitude, and behavior (Maryatun, 2013).

Someone could influence others to have the same value and sense of commitment in the relation with peers. Therefore, the role of peers was very meaningful in obtaining information that would affect the attitude and behavior (Burgess et al., 2005). The strong influence of peer groups came from the desire to be accepted by the group (Tomé et al., 2012).

In this study, most of the research subjects have high peers influence. This showed that some of the society got influence from peers in order to increase the mother's visit to posyandu. Peers can have a significant impact on maternal behaviors to visit posyandu. Mothers would easily exchange the information with peers about the benefits of Posyandu in order to 
increase the maternal motivation to visit Posyandu.

\section{The relationship between pos- yandu facility and mother's visit to posyandu}

There was a relationship between posyandu facility and mothers' visit to posyandu which was statistically significant. Mothers who have good posyandu facility were more likely to visit the posyandu compared to mothers who have poor posyandu facility.

The result of this study was in line with a study by Miskin, Rompas and Ismanto, (2016), which stated that there was a meaningful relationship between posyandu facility and mothers' visit to posyandu. One of the posyandu's facilities was the activeness of the cadres who play a role in the success of the posyandu program. Mother who gets good posyandu facilities was more likely to visit the posyandu.

Facility was a potential value possessed by a certain material or element in life. Resources were not always physical, but also non-physical (intangible) (Darmawan, 2010). Resources can also be anything that allowed a person to gain satisfaction. Facilities were the infrastructure to do or make something easier. Resources can also be considered as a tool (Frisdiantara and Graha, 2013).

Resource planning included power, facilities, and costs. The power included professional staff and cadres. Professional staff which required for posyandu services included midwives, nurses, and vaccinators to establish a full service team at posyandu with the availability of health personnel at health center (Reihana and Duarsa, 2012). The need of cadres who served at posyandu was at least 5 peoples. The facilities needed were weight scale, growth and development monitoring book, vaccines (tetanus toxoid, BCG, polio, measles, and Hepatitis B), vitamin $\mathrm{A}$, oralite, posyandu kit, and pos- yandu record (register book, and current recording and reporting forms as Posyandu information system) (Sulaeman, 2016).

In this study, most of the research subjects have good posyandu facilities. This showed that most of the society have obtained posyandu services properly. Mothers who live in neighborhoods with good posyandu facility have a greater opportunity to visit posyandu rather than mothers who have poor posyandu facility.

\section{The effect of posyandu on mother's visit to posyandu}

Posyandu was one of the community-based health efforts that was managed and organized from, by, for, and with the community in the implementation of health development to empower the community and provide convenience to the community in obtaining basic health services to accelerate the degradation of maternal and infant mortality (Sulaeman, 2016).

As one of the places of community health services which directly contact the community at the lower level, there were several health service activities in posyandu including 5 (five) priority posyandu programs; Maternal and Child Health (MCH), Family Planning (FP), immunezation, nutrition monitoring, and prevention of diarrhea (Syamsi, 2017).

Noerjoedianto et al. (2014), stated that the government has managed to improve the performance of Posyandu through Ministry of Home Affairs' circular letter in 2001. This provided significant improvements, especially in inactive posyandu such as pratama and madya, therefore, it could increase posyandu activeness including mother's visit to posyandu.

\begin{tabular}{r}
\hline REFERENCES \\
\hline Bandura A (1994). Self-Efficacy', Encyclo- \\
pedia of human behavior, 4(1994): \\
71-81. doi: 10.1002/9780470479216.-
\end{tabular}


corpsyo836.

Bandura A, Locke EA (2003). Negative selfefficacy and goal effects revisited. Journal of Applied Psychology, 88(1): 87-99. doi: 10.1037/0021-9010.88.1.87.

Burgess V, Dziegielewski SF, Green CE (2005). Improving comfort about sex communication between parents and their adolescents: practice-based research within a teen sexuality group. Brief Treatment and Crisis Intervention, 5(4): 379-390. doi: 10.1093/brief-treatment/mhio23.

Darmawan AAKN (2010). Faktor-faktor yang mempengaruhi perilaku kunjungan masyarakat terhadap pemanfaatan pelayanan posyandu di Desa Pemecutan Kelod Kecamatan Denpasar. Dunia Kesehatan, 5:29-39. Available at: http://binausadabali.ejurnal.info/index.php/kesehatan/article/view/15/6.

Efendi H, et al. (2017). Dukungan keluarga dalam manajemen penyakit hipertensi family support in hypertension disease's management. 6: 34-40.

Frisdiantara C, Graha AN (2013). Pengaruh dimensi pelayanan dan dimensi fasilitas terhadap kepuasan mahasiswa pada Universitas Kanjuruhan Malang. 9: 106-119.

Humaira H, Jurnalis YD (2016). Artikel penelitian hubungan status gizi dengan perkembangan psikomotorik balita di wilayah kerja Puskesmas Lapai Padang tahun 2014. 5(2): 402408.

Idaningsih A (2016). Faktor-faktor yang berhubungan dengan kunjungan balita ke posyandu. Jurnal Ilmiah Indonesia, 1(2): 16-29.

Kurniawan A (2017) Hubungan tingkat pengetahuan dan efikasi diri dengan pelayanan kader posyandu lansia di
Desa Mancasan, Kecamatan Baki. Surakarta.

Maryatun (2013). Peran teman sebaya terhadap perilaku seksual pra nikah pada remaja di SMA Muhammadiyah 3 Surakarta. Jurnal Gaster, 10(1): 3947.

Miskin S, Rompas S, Ismanto AY (2016). Hubungan pengetahuan ibu dan peran kader dengan kunjugan balita di posyandu wilayah kerja Puskesmas Pineleng. E-journal Keperawatan, 4: 1-6.

Nazri C, et al. (2015). Factors influencing mother's participation in posyandu for improving nutritional status of children under-five in Aceh Utara district, Aceh province, Indonesia. BMC Public Health. BMC Public Health, 16(1): 69. doi: 10.1186/s12889-016-2732-7.

Noerjoedianto D, Amir A, Nurhusna H (2014). Penguatan kader posyandu dalam upaya deteksi dini kesehatan ibu, bayi dan balita di wilayah Kecamatan Telanaipura Kota Jambi tahun 2013, Jurnal pengabdian masyarakat.

Rahman MH, Luthviatin N, Istiaji $\mathrm{E}$ (2013a). Determinan niat masyarakat untuk berkunjung ke Posyandu di wilayah kerja Puskesmas Jelbuk Kabupaten Jember.

Rahman MH, Luthviatin N, Istiaji E (2013b). Determinan niat masyarakat untuk berkunjung ke posyandu di wilayah kerja puskesmas Jelbuk Kabupaten Jember (Determinants of people's intention to visit posyandu in health center of Jelbuk Jember Regency). Artikel Ilmiah Hasil Penelitian Mahasiswa.

Reihana, Duarsa ABS (2012). Faktor-faktor yang berhubungan dengan partisipasi ibu untuk menimbang balita ke posyandu. 20(3): 143-157. 
Sefrina F, Latipun (2016). Hubungan dukungan keluarga dan keberfungsian sosial pada pasien skizofrenia rawat jalan. 04(02): 140-160.

Sulaeman ES (2016) Pemberdayaan masyarakat di bidang kesehatan.

Syamsi AA (2017). Pelayanan kesehatan bagi balita di Posyandu Cempaka 2 Kelurahan Berbas Tengah Kecamatan Bontang Selatan Kota Bontang', 5: $5243-5252$.

Tomé G, et al. (2012). How can Peer group influence the behavior of adolescents: explanatory model. Global Journal of
Health Science, 4(2): 26-35. doi: 10.5539/gjhs.v4n2p26.

Utami RB, Damayanti DF (2012). Faktorfaktor yang berhubungan dengan perilaku ibu dalam melakukan kunjungan ke posyandu. Jurnal Vokasi Kesehatan, 2003: 245-252.

Yigibalom L (2013). Peranan interaksi anggota keluarga dalam upaya mempertahankan harmonisasi kehidupan keluarga di Desa Kumuluk Kecamatan Tiom Kabupaten Lanny Jaya. II(4): 119. 